\section{From heterogeneity to harmonization? Recent trends in European health policy}

\author{
Da heterogeneidade à harmonização? Tendências \\ recentes na política de saúde européia
}

\author{
1 Institute for Medical \\ Sociology, University of \\ Frankfurt, Frankfurt, \\ Germany. \\ 2 Department for Public \\ Policy and Strategic Planning \\ at the Executive Board, \\ German Metalworkers' \\ Union, Frankfurt, Germany. \\ Correspondence \\ T. Gerlinger \\ Institute for Medical \\ Sociology, University of \\ Frankfurt. \\ Haus 9B, Theodor-Stern-Kai 7, \\ 60590 Frankfurt, Germany. \\ gerlinger@em.uni-frankfurt.de
}

\begin{abstract}
In the European Union (EU), health policy and the institutional reform of health systems have been treated primarily as national affairs, and health care systems within the EU thus differ considerably. However, the health policy field is undergoing a dynamic process of Europeanization. This process is stimulated by the orientation towards a more competitive economy, recently inaugurated and known as the Lisbon Strategy, while the regulatory requirements of the European Economic and Monetary Union are stimulating the Europeanization of health policy. In addition, the so-called open method of coordination, representing a new mode of regulation within the European multi-level system, is applied increasingly to the health policy area. Diverse trends are thus emerging. While the Lisbon Strategy goes along with a strategic upgrading of health policy more generally, health policy is increasingly used to strengthen economic competitiveness. Pressure on Member States is expected to increase to contain costs and promote market-based health care provision.
\end{abstract}

European Union; Health Policy; Health Systems
Thomas Gerlinger 1

Hans-Jürgen Urban 2

\section{Health policy in Europe: a domain of the individual Member States}

The European Union (EU) covers 25 Member States with some 460 million inhabitants. In the early $21^{\text {st }}$ century, the EU is still characterized by the predominance of economic integration. The Common Market established the free movement of goods, capital, persons, and services among Member States. Meanwhile, there is a lack of corresponding political competencies at the European level, especially in the field of social policy in general and health policy in particular 1,2.

European integration has had little impact on national health policy thus far. It is true that the European Treaty obliges EU institutions to focus on improving the population's health and to ensure a high level of health protection in all fields of Community policy. Since the 1990s, a number of programs empowering EU institutions to protect public health have been launched by the EU Commission on the basis of its competencies in guarding against disease ${ }^{3}$. However, the legal obligations of the EU Treaty involve rather broad provisions, and the European institutions are subject to the principle of subsidiarity when exercising their authority in areas of social and health policy and other affairs. The EU is only allowed to promote cooperation between Member States and to complement their policies. Due to this narrowly defined scope of action, the EU has explicit legislative powers in only a few spheres 
of preventive policy, the most important being workplace health and safety and various aspects of health-related consumer protection. In these areas the EU sets supranational minimum standards that the Member States must meet. By contrast, the authority to shape the health care system lies entirely with the Member States (Article 152, par. 5), which are thus individually responsible for:

- The type and extent of coverage afforded by the social security system in case of illness (i.e., financing of payments and scope of services);

- Organization of the health care system, including institutional structures and the division of labor among the professional groups;

- The decision on the distribution of authority over the regulation of health care systems.

In early $21^{\text {st }}$ century Europe, health policy (like other social policies) remains mostly a national affair. Attempts to achieve harmonization and Europeanization have usually foundered due to the disparate levels of economic development in the Member States, each country's established institutional arrangements governing health policy, and the dissimilar traditions of social policy across the EU. In addition, governments of the Member States have two key interests in maintaining their own policy leverage. First, the nature and scope of the social safety net in case of illness can affect government budgets and labor costs of domestic companies - factors that national governments, as calibrators of international competition to attract industry, would prefer to shape at their own regulatory discretion. Second, social policy and its attendant guarantee of basic public services is a "valuable source of political legitimation" 4 (p. 31). So far, only the individual countries have been able to tap this source. Entitlement to proper medical services is a cornerstone of the welfare cultures in the industrially developed capitalist states and is seen almost as a kind of civil right "Health care matters (...) Being able to go to the doctor is one of the hallmarks of citizenship in most advanced industrial countries" 5 (p. 35). Few if any governments are in a position to back out of their ensuing obligations, and successfully meeting such commitments is sure to be acknowledged by the electorate - an option that legitimacy-dependent national governments understandably do not wish to forgo. When it comes to exchanging state social benefits for acceptance or votes, health policy lends itself better than nearly any other field. This vested interest of the countries was also expressed and institutionally anchored in the division of responsibilities and authority among EU institutions and Member States in European Community law. In any case, it proved impossible to harmonize the health care systems of the EU Member States by imposing supranational legal obligations.

Although national health care reforms since the 1980s have often resorted to similar regulatory instruments, and although certain convergent trends are therefore identifiable, they are not due to the establishment of any transnational regulatory authority ${ }^{5}$. These reforms and trends are mainly a response to shared root conditions of economic and financial policy, to comparable health problems, and in many cases to similar shortcomings in the various medical care systems. Despite such convergence, the wide range of health care systems persists, with serious differences in the structure of medical services, funding, and regulatory framework 6,7 .

\section{The heterogeneity of health care systems in Europe}

Due to the specific traditions of EU Member States, there are a wide variety of national health care systems in Europe 8. In order to illustrate their heterogeneity we select five countries representing different types of Member States: Portugal as an example of a Southern European Member State, Germany as the largest economy in the EU and representing Continental Europe, Sweden as the most prominent Northern European member, Poland as an example of the Eastern European states that joined the Union in 2004, and the United Kingdom as a special case.

As Table 1 shows, there are differences in the economic framework of health care. Gross domestic product (GDP) and health expenditures differ considerably.

Resources for health care delivery also differ widely among the Member States. The number of practicing physicians per 1,000 inhabitants in Germany is $50 \%$ greater than in the UK, while the numbers of practicing nurses in Sweden and hospital beds in Germany are 2.5 times those of Portugal (Table 2).

Nevertheless, the heterogeneity of health care systems is not confined to economic performance or quantitative indicators of health care delivery, but also affects the overall organization of services. In many Member States, health care is organized as a national health service (UK, Sweden), while in others (Germany, France, Netherlands) it is based on a health care insurance system. Against this background, differences between health care systems affect the structure of their supply, financing, and regulation.

Supply structure includes the nature and scope of benefits covered by public finance, the division of labor between health professions 
Gross domestic product (GDP) and health expenditure in selected Member States of the European Union, 2003.

\begin{tabular}{lcc}
\hline & $\begin{array}{c}\text { GDP } \\
\text { (US\$ PPP, per capita) }\end{array}$ & $\begin{array}{c}\text { Total health expenditure } \\
\text { (US\$ PPP, per capita) }\end{array}$ \\
\hline Portugal & 18,725 & 1,797 \\
Germany & 27,094 & 2,996 \\
Sweden & 28,881 & $2,594 *$ \\
Poland & 11,524 & 677 * \\
United Kingdom & 29,826 & 2,231 * \\
\hline
\end{tabular}

* 2002 .

PPP: purchasing power parity.

Source: Organisation for Economic Cooperation and Development 8.

Table 2

Number of physicians, nurses, and hospital beds per 1,000 inhabitants in selected Member States of the European Union, 2003.

\begin{tabular}{lccc}
\hline & Practicing physicians & Practicing nurses & Hospital beds \\
\hline Portugal & 3.3 & 4.2 & 3.6 * \\
Germany & 3.4 & 9.7 & $8.9 *$ \\
Sweden & $3.3 *$ & 10.2 * & - \\
Poland & 2.5 & 4.9 & - \\
United Kingdom & 2.2 & 9.7 & 4.2 \\
\hline
\end{tabular}

* 2002 .

Source: Organisation for Economic Cooperation and Development 8.

(physicians and nurses, general practitioners and specialists), and the rules for access to health care institutions. In some Member States, especially those relying on a national health service, outpatient care is provided exclusively by general practitioners, while specialized care is restricted to hospitals; other countries, predominantly with health insurance systems, offer a free choice between general practitioners and specialists in outpatient care, while hospitals are usually allowed to deliver inpatient care only. The financial structure includes both the level of health care spending and modalities for funding health services: some systems are predominantly funded by taxes, others by income-related insurance contributions. The distribution between public and private funding also varies, as does the ratio of publicly to privately insured individuals. Some national health care systems and health insurance-based systems (e.g. Netherlands) provide coverage for all citizens, while in other systems (e.g. Germany) a minority of the population is not subject to mandatory health care insurance.
Finally, the regulatory structure includes both the decision-making structures (i.e., actors and processes in health care regulation) and the underlying regulatory mechanisms. In health insurance systems, the government's role is usually limited to defining a regulatory framework, and competencies for detailed regulation are delegated to corporative actors. In contrast, in countries based on a national health service, government and public authorities themselves more often make the rules, even with regard to specific problems. Although most EU Member States rely increasingly on market mechanisms, the respective importance of government, corporative, and market-based regulatory elements still differs from country to country.

\section{Repercussions of European integration for national health policy}

Despite the above, it would be a distortion to assert that there is no encroachment of Member 
States' autonomy where health policy is concerned. European integration has indeed gained importance for health policy in the EU Member States over the years and in some ways has generated standards for national policy. This growth in supranational influence has occurred in several ways 2:

- By creating and deepening the political union, the EU spelled out and successively broadened the authority and obligations of its institutions to act on health matters, as mentioned above. In particular, EU institutions have been assigned explicit regulatory authority in some fields relevant to prevention policy since the late 1980s.

- The creation of a single European market limits the freedom of the Member States to manage their own health policies. Several rulings by the European Court of Justice clearly demonstrated that although Member States are responsible for structuring their health care systems, they must comply with the "four freedoms" (free movement of goods, persons, capital, and services) under the single market, particularly cross-border entitlement to health services.

- The obligations entailed in the four freedoms somewhat curtails the latitude for shaping national regulatory systems. For example, tension has arisen between European and national legislation on competition, especially for regulation of health care systems. The German system is a good example. It is moot whether collective contracts (which are central to it) are compatible with the proscription of agreements that prevent, restrict, or distort competition within the Common Market (Art. 81, EC Treaty) and on the "abuse of a dominant position within the common market" (Art. 82, EC Treaty). A declaration by the European Court of Justice that collective health insurance contracts violate the Treaty on European Union could nullify key elements of the regulatory system in German health policy. Although rulings by the European Court of Justice have not indicated that the collective contract system (permitted under German health insurance law) will be classified as incompatible with European Market law, there is obviously a trend towards trans-nationalization of health policy governance.

\section{The Lisbon strategy of competition and the open method of coordination}

European integration is influenced largely by the establishment of the Euro financial regime (with the growth and stability pact and the function of the European Central Bank at its core). Due to increasing economic difficulties, the EU has emphasized competition policy as a new path to integration, an idea that is systematically expressed in the vision formulated at the European Summit in Lisbon 2000. The overriding objective is to make the EU "the most competitive and $d y$ namic knowledge-based economy in the world" 8 (p. 2). For the European Council, achieving this goal means having:

- To consolidate public finances on a lasting basis;

- To accelerate the integration of underemployed population groups into the labor market; and

- To modernize (as the term is used) the social protection systems in the EU.

The Lisbon redirection of competition policy engenders economic, fiscal, and employment policy standards and imperatives that radiate into neighboring policy fields, including health. Health policy is gaining considerable importance because it is seen as having an immediate bearing on the new integration strategy's success. Under pressure from the targets set by the growth and stability pact, the countries are trying to extend strict budget discipline to their public health care systems as well. Additionally, cultivating the health of human resources is expected to help build the potential for productivity, just as encouraging the expansion of European health management is expected to build employment potential. Both objectives are part of a fiscal consolidation policy. The emerging field of European health policy thus derives its developmental energy from this nexus of fiscal, competition, and employment policy.

This shift fundamentally alters the socioeconomic and political conditions surrounding health policy in Europe. In this context, social policy, specifically health policy, is increasing in status and changing its focus. The new strategic appreciation is apparent in the systematic integration into European economic and growth policy. The functional objective of social and health policy has been redefined. Redistribution, the compensation of social risk, and the other classical goals are no longer the primary criteria. The main thrust now is to take the European model of development and steer it toward competition as effectively as possible.

The open method of coordination is pivotal in this reassessment and realignment of European social and health policy. It should improve voluntary cooperation and the transfer of sound procedures between the EU Member States, helping them to continue developing their own national policies. The salient point is to increase the efficiency with which the national policies in the various fields are integrated into efforts to 
achieve the overall strategic goal, namely greater competitiveness of a European knowledge-based economy by consolidating public budgets and modernizing social protection.

The open method of coordination was defined for the first time in the conclusions drawn by the Council of Lisbon. It encompasses the following core elements 8 :

- Setting guidelines for the development of individual policy areas, including a timetable for achieving short, medium, and long-term objectives;

- Establishing quantitative and qualitative indicators and benchmarks to facilitate comparison of national practices and identify sound processes;

- The adoption of European guidelines in the Member States' policies by developing concrete objectives and enacting appropriate measures;

- The regular supervision, evaluation, and mutual examination of the measures taken and progress achieved.

As defined at the Lisbon Summit, the open method of coordination differs in general from past policy strategies and procedural practice in distinct ways that mark it as a new regulatory model:

- The open method of coordination is a procedure for developing common policies that go beyond the traditional rule- and norm-setting established in the Treaty on European Union - that is, beyond predominantly issuing guidelines and regulations. The idea is to foster political commonalities among the Member States not by transferring resources of control (e.g., rights and money) but rather by advancing a process of coordination and learning ("soft regulation") that leaves the formal authority of the Member States intact 9;

- The European Council, European Commission, and EU Council of Ministers become the prime actors in European-wide coordination. The key role lies with the European Council, explicitly accorded a strengthened managing and coordinating function and responsible for supervising the implementation of strategies and processes and taking corrective action if necessary ${ }^{10}$;

- The purpose is to promote political commonalities among the Member States by engaging in the desired joint process of coordination and learning, which tends to rely on "communicative and interactive" forms of control 11 and dispenses with binding targets and formal sanctions;

- The open method of coordination thus follows a kind of "third way" between the classical search for harmonization and mere recommendations or intergovernmental agreements $9,12,13,14$. This process attempts to inaugurate the transition from a strategy of harmonizing institutions to one of harmonizing policy objectives. Convergent developmental processes are to be achieved through EU-wide coordination of policy formulation, without formally jeopardizing national sovereignty. The open method of coordination therefore links two contrasting interests: that of EU institutions in broadening their influence on health policy and that of the Member States in preserving their sovereignty.

The open method of coordination is to be applied to health policy (in addition to employment, pension, and poverty and social exclusion issues). In several reports and other documents approved by the EU since the Lisbon Summit, the European Commission and European Council describe the problems that the health care systems of Member States have in common and define EU-wide goals for reform of health care systems 15,16. Challenges that health policies in Europe share and must address include:

- The increasing proportion of elderly in the total population;

- The impact of new technologies and therapies on medicine; and

- The mounting popular demand for medical care and appropriate services as living standards and levels of education improve.

The Commission noted that these matters raise the question of budget management and escalate the pressure to curb costs. It is therefore necessary to develop "clear, transparent, and effective evaluation mechanisms" 16 (p. 7). Thus, the European Commission unequivocally makes the long-term financial viability of health policy a regulatory premise of economic and fiscal policy in the EU.

The Commission formulates three main health policy objectives in the EU to be achieved simultaneously 16 :

- Universal access to high-quality health care;

- Increased transparency and quality of health care systems by evaluating medical procedures and service structures;

- Continuation of reforms aimed at cost containment (accompanied by efforts to consolidate public budgets and ensure adequate funding for health care).

In view of the above-mentioned analysis and goals, the EU concludes that Member States' health care systems must be adapted to meet the demands of a dynamic, growth-oriented economy. In the Council's view, the changes must involve not only cutting costs but also modernizing the systems in order to promote efficiency. This message is still the thrust of the Commission's analyses and proposals for action. 


\section{Presumable impact of Europeanization on health policy}

There are indications that the open method of coordination expands the opportunities for coordinating national health policies. However, it also involves practical difficulties and risks for the delivery of health care.

\section{Problems specific to the field of health policy}

The open method of coordination's methodological drawbacks are particularly daunting given the special nature of health as a focus of regulatory policy. Even as benchmarking and best practices spread to more policy fields and organizations, research has increasingly identified their limits and problems 17 . In principle, when comparing systems, the complications tend to increase with the complexity of the systems for action and policy fields. The effect of individual control elements cannot be grasped precisely, because they only work under specific circumstances. Nor can individual elements be arbitrarily transposed to other contexts, since they may entail unforeseen side effects when embedded in a different set of conditions.

These fundamental problems are especially serious in the evaluation of health care systems. Unlike unemployment insurance or old-age pension systems, health care systems do not organize monetary redistribution and transfers. Rather, health care systems are complex economic sectors or systems of social action centered on rendering personal services. In terms of institutions, entitlements, and norms, these systems are extremely heterogeneous and complex 18 . The usual regulatory instruments (e.g., forms of compensation and institutional arrangements of health service providers) do not lead to particular results "per se". Instead, they operate within the context of a specific system or in interaction with other elements in it, thus exacerbating the problem with transposition.

In addition, the social complexity of health as a "good" produces problems. Services provided through health policy relate to the treatment of diseases, health promotion, or both. Health and illness are the results of an almost overwhelming number of variables that can occur in different combinations. In most cases, the utility of certain interventions can only be assessed reliably in the long term, if ever.

Given the heterogeneity of the health care systems and the societal complexity of health as a phenomenon, it is difficult to imagine how a benchmarking process is supposed to identify examples of best practices that might serve as universal standards for providing effective and efficient services. The definition of indicators and benchmarks always reflects individual interests and power relations, thus further complicating the problem.

If nothing else, this conundrum demands exceptionally high quality data on which to base health policy. Such quality cannot be taken for granted. Dissimilar national data collection methods and statistical and conceptual distinctions in the individual EU countries seriously restrict even rough comparisons of resources and their use in EU Member States. Limitations on the measurement of health care outcomes are even more serious. Even where such comparative data exist, it is difficult for the observed health care outcomes to be causally attributed to discrete features of the respective systems.

\section{Problems of inter-policy-related} goal conflicts

The open method of coordination entails a number of problems even beyond the friction in the health policy field 9 . One such problem pertains to cooperation between actors and to their competencies at the national and European levels. Another source of tension stems from the substantive underpinnings of the guidelines and the compatibility of policy goals.

Procedural tensions and policy entanglements result from the distribution of tasks and competencies between national and supranational actors. The Europeanization of health policy through the open method of coordination is utterly incongruent with a unidimensional transfer of competency from the national to the European level. Political arenas at the European level are forming in which the European Court of Justice, European Commission, and European Council pursue health policy more actively and decisively than in the past. Provisions defined at the European level are narrowing the policy options available at the national level, while key actors in the national health care systems are using the European decision-making processes to achieve their own interests and strategy options.

These new kinds of linkage between national and European health policy generate tensions in the field. On the one hand, rulings by the European Council and European Commission stress that the principle of subsidiarity applies to this policy field as well, and that the special national aspects of health care systems must be considered when preparing European guidelines. Meanwhile, reforms are expected to adopt certain shared criteria and objectives and hence lead to a particular (albeit still unspecified) convergence of charac- 
teristics and goals across the systems. Experience with European-wide negotiations has shown that the Member States usually press for goals and instruments that require the least adaptation at the national level. If such practice also dominates the application of the open method of coordination, agreement will probably not extend beyond the lowest common denominator. The approved guidelines will subsequently be quite vague, and Member States will probably feel little pressure to adapt.

It is also conceivable that Member State governments are using the European level to champion reform strategies that they see as desirable but whose acceptance would either founder due to national power constellations and barriers to reform or cost a great deal of support. But even where European guidelines are considered unwelcome, the open method of coordination can exert substantial pressure to adapt despite national sovereignty, because goals that are based on European-wide agreement, judged important to competition and stability policy, and communicated through national and European media 19 can quickly become the parameters for national policy. Politically delinquent governments (the name-and-shame strategy) ought to suffer the consequences. However, such a development requires the emergence of a European public that influences the national discourses on health policy. Only then can one plausibly assume that European guidelines will put pressure on national veto-players to adapt.

But the main problems for the implementation of the open method of coordination will probably arise from the menacing conflicts in goals that could ensue from utilizing the health policy (and health policy targets) of the European Council and European Commission for purposes of competition policy and consolidation of public budgets. The goal of ensuring a high level of social protection and open access to health care services implies a high level of public spending, which would clash with the cost-cutting needed to achieve the Maastricht stability criteria and would thus weaken the EU. Conversely, the intended utilization of health policy to promote competition policy and cost containment can encourage privatization of medical treatment, endangering the goal of ensuring a high level of social protection and unhindered access to health care services.

But if the implicit or explicit goals are not achievable all at once and if goal conflicts are foreseeable, then the political decision-makers setting the health policy agenda will eventually have to rank health policy priorities. Because the calculation of the annual public debt includes both the state health systems and quasi-governmental social insurance institutions under public law, it is not surprising that the financial development of the health systems is monitored to keep from potentially jeopardizing fiscal stability. This strategic logic for anchoring the coordination of health policy firmly in the European financial regime's stability targets explains why the policy goals of consolidation can be expected to take priority over those of medical services. Meanwhile, cost containment may well take priority over the goal of ensuring comprehensive, high-quality care when setting indicators and benchmarks.

The European Commission's report about the future of the health care system and care for the elderly 16 consistently points to such prioritization. It emphasizes that health policy is vital for the implementation of quality and viability strategies, which must respect the principles set in the Broad Economic Policy Guidelines for 2001. Health policy thereby focuses on the economic policy premises designed to consolidate public budgets and stabilize prices and on the accumulation of physical and human resources in the private sector. Accordingly, it appears absolutely logical that cost containment be given preference over the goal of ensuring comprehensive, high-quality care in the setting of indicators and benchmarks.

Recent experience supports this expectation. At the Brussels Summit in March 2005, against the background of the economic crisis and rising unemployment rates, the European Commission and European Council reformulated the Lisbon Strategy. The renewed "Lisbon Strategy" reemphasizes the focus on growth and employment 20,21,22,23. The European Council instructed the Commission to develop integrated guidelines for 2005-2008. These guidelines will be valid for three years and will be implemented into national reform programs to be presented by Member States in autumn 2005. In those programs, countries are supposed to state precisely what measures they intend to take in order to support growth policy. All aspects relevant to the Lisbon Strategy, including health policy, will be integrated into one report, thus further strengthening the connection between health policy and economic policy.

Priorities like these would tie European health policy into trends that have existed for some time at the national level. Since the 1980s, cost containment and consolidation have acquired higher status as a "fiscal imperative" of government policy goals in the health field within the developed capitalist democracies. In the 1990s, the specter of economic stagnation and the pressure resulting from the steady cost increases in 
national health care systems further fueled this trend, worsening the conditions for funding innovative forms of care and threatening to raise greater social barriers to services. The longer the ensuing scarcity of health system funding persists, the more likely the policy problems for medical services.

The open method of coordination as an accelerator of reform

One conceivable way of deescalating this conflict between the policy goals of fiscal consolidation and the improvement of medical services is to pursue reform policies that develop the existing potential for thrift and efficiency in national heath care systems. This approach would be fully compatible with the goals of coordinating health policy at the European level, while addressing structural shortcomings. The open method of coordination could help enhance the odds of prevailing over such defects and defeating obstacles to innovation 10. Systematic collection and comparative analysis of individual health care systems data when preparing benchmarking reports could lower the transaction costs of gathering information, simplify the recognition of flaws, and thereby improve the conditions for broad learning effects. The open method of coordination could definitely help speed up reform by functioning mainly as a clearinghouse for information. Health care systems in Member States offer many suitable opportunities for such accelerated modernization efforts.

Again, Germany is a good example. In German health policy and among scientific experts, there is broad consensus that the system of statutory health insurance in Germany suffers from lack of efficiency and quality. Compared to other systems in the world, it combines high costs and only mediocre health results. Structural weaknesses of the medical service system are blamed for the most part, especially the lack of preventive health policy, the marked segregation of medical service sectors, and over-reliance on specialized services. Defying every attempt at reform, these structural drawbacks in the German health care system are exceedingly resistant to change. If international comparison were to intensify awareness of (for example) the segregation between outpatient and inpatient care or the high representation of specialists in outpatient medical services, it could facilitate public discussion and criticism and help create a public climate conducive to reforming and overcoming these deficiencies. Thus, pressure could grow to change structures identified as inefficient or sub-optimal and adapt them to superior models.

\section{Conclusions}

In principle, the open method of coordination appears to be able to help streamline the supply structures in the health care systems in EU Member States in a way that decreases the pressure to ration health services. However, the contextual conditions and strategic bearings of initiatives coming from the EU and finding their way into national health policies through the open method of coordination give reason for great skepticism:

- First, the EU's political elites are not inclined to embark on the contentious and risky path of challenging powerful vested interests, particularly on matters of health policy. The preferred road to success in the international competition to attract industry is to downsize the social security net and emphasize "personal responsibility".

- Second, strengthening the European level of action in health policy does not eliminate the alignments of national forces and contextual conditions that have already thwarted or hampered modernization of medical care structures in Member States, not least in Germany.

The functional embedding of the open method of coordination in a specific vision of competition policy, the obligation of EU Member States to adopt the provisions of the European Economic and Monetary Union, and the policyrelated regulatory and control problems specific to the health sector feed the concern that using the open method of coordination in the field of health policy could eventually degrade social protection in the face of illness.

Therefore, it is wholly probable that the outlined changes in the different arenas of Europe's multilevel system will turn out to be policy-fieldspecific components of a process that has been described as a transition to a new European social model.

Embedded in the European financial regime and the revamping of competition policy along the lines of the Lisbon strategy, a new vision is beginning to surface in health policy and other fields. In the traditional European social model, social policy was understood as an expression of public responsibility for the population's social welfare. The new vision now replaces "government interventionism in the interest of social policy" with "government interventionism in the interest of competition policy" 24 (p. 279).

If it succeeds, the foremost goal of strategies for active social policy would no longer be to correct adverse economic and social distributional effects of the market and to ensure protection against the social risks of life. It would be replaced 
by the goal of adapting the European model of development to the exigencies of competition in a transnationalized economy and of using social and health policies primarily as resources for in- creasing productivity and competition. Against this background, increasing pressure is to be expected on unhindered access to high-quality health care.

\section{Resumo}

Na União Européia, as políticas de saúde e a reforma institucional dos sistemas de saúde têm sido tratadas principalmente como questões nacionais, levando a diferenças importantes entre os sistemas dentro da União. Entretanto, o campo da política de saúde está passando por um processo dinâmico de europeização, estimulado pela mudança recente para uma economia mais competitiva, conhecida como a Estratégia de Lisboa, enquanto as exigências regulatórias da União Econômica e Monetária estão promovendo a europeização da política sanitária. Além disso, o método conhecido como coordenação aberta, que representa uma nova modalidade de regulamentação dentro do sistema europeu com múltiplos níveis, é aplicado cada vez mais à área de política sanitária. Enquanto a Estratégia de Lisboa acompanha a melhoria estratégica da política de saúde no sentido mais geral, esta política é utilizada cada vez mais para fortalecer a competitividade econômica. A previsão é de que a pressão crescente sobre os países membros irá conter custos e promover a oferta de serviços de saúde com base no mercado.

União Européia; Política de Saúde; Sistemas de Saúde

\section{Contributors}

T. Gerlinger wrote the sections Health Policy in Europe: a Domain of the Individual Member States, The Heterogeneity of Health Care Systems in Europe and The Lisbon Strategy of Competition and the Open Method of Coordination. H-J. Urban wrote the sections Repercussions of European Integration on National Health Policy, Presumable Impact of Europeanization on Health Policy, and Conclusions. 


\section{References}

1. Leibfried S, Pierson P, editors. Standort Europa. Sozialpolitik zwischen Nationalstaat und Europäischer Integration. Frankfurt: Suhrkamp; 1998.

2. McKee M, Mossialos E, Baeten R, editors. The impact of EU law on health care systems. Brussels: Peter Lang; 2002.

3. Topan A. European Governance in der Gesundheitspolitik - Wirklichkeit oder Utopie? Sozialer Fortschritt 2003; 52:247-53.

4. Pierson P, Leibfried S. Mehrebenenpolitik und die Entwicklung des sozialen Europa. In: Leibfried S, Pierson P, editors. Standort Europa. Sozialpolitik zwischen Nationalstaat und Europäischer Integration. Frankfurt: Suhrkamp; 1998. p. 11-57.

5. Freeman R, Moran M. Reforming health care in Europe. West Eur Polit 2000; 23:35-58.

6. Blank RH, Burau V. Comparative health policy. Basingstoke/New York: Palgrave; 2004.

7. Rothgang H, Cacace M, Grimmeisen S, Wendt, C. The changing role of the state in healthcare systems. Eur Rev 2005; 13 Suppl 1:187-212.

8. Organisation for Economic Co-operation and Development. Health data 2005. Paris: Organisation for Economic Co-operation and Development; 2005.

9. Radaelli CM. The open method of coordination: a new governance architecture for the European Union - preliminary report. Stockholm: Swedish Institute for European Policy Studies; 2003.

10. Urban HJ. Europäisierung der Gesundheitspolitik? Zur Evolution eines Politikfeldes im europäischen Mehrebenensystem. Berlin:Wissenschaftszentrum Berlin für Sozialforschung; 2003.

11. Tidow S. Benchmarking als leitidee. Zum Verlust des Politischen in der europäischen Perspektive. Bl Dtsch Int Polit 1999; 44:301-9.

12. De la Porte C, Pochet P, editors. Building social Europe through the open method of co-ordination. Brussels: PIE-Peter Lang; 2002.

13. Hodson D, Maher I. The open method as a new mode of governance: the case of soft economic policy co-ordination. J Common Mark Stud 2001; 39:719-46.
14. Jorens Y, editor. Open method of coordination. Objectives of European health care policy. BadenBaden: Nomos; 2003.

15. European Council. Presidency conclusions: Göteborg European Council, 15 and 16. Brussels: European Council; 2001.

16. European Commission. The future of health care and care for the elderly: guaranteeing accessibility, quality, and financial viability. Brussels: European Commission; 2001.

17. Szulanski G, Winter S. Best-practice - nicht immer übertragbar. Harvard Business Manager 2002; 24:44-53.

18. Holland W, Mossialos E, editors. Public health policies in the European Union. Aldershot: Ashgate; 1999

19. Rieger E. Die sozialpolitische Gegenreformation. Eine kritische Analyse der Wirtschafts- und Sozialpolitik seit 1998. Polit Zeitgesch 2002; 46/47:3-12.

20. European Commission. Modernising social protection for the development of high-quality, accessible and sustainable health care and long-term care: support for the national strategies using the open method of coordination. Brussels: European Commission; 2004.

21. European Commission. Integrated guidelines for growth and jobs (2005-2008). Brussels: European Commission; 2005.

22. European Commission. Working together for growth and jobs. A new start for the Lisbon strategy. Brussels: European Commission; 2005.

23. European Council. Presidency conclusions: Brussels European council. Brussels: European Council; 2005.

24. Aust A, Leitner S, Lessenich S. Konjunktur und Krise des Europäischen Sozialmodells. Ein Beitrag zur politischen Präexplanationsdiagnostik. Polit Vierteljahresschr 2002; 43:272-301.

Submitted on 26/Jun/2006

Final version resubmitted on 16/Feb/2007

Approved on 02/Mar/2007 